\title{
100 LET UGLEDNEGA ŠKOTSKEGA INŠTITUTA THE ROWETT RESEARCH INSTITUTE: VPLIV NA RAZVOJ MIKROBIOLOGIJE V PREHRANI DOMAČIH ŽIVALI IN LJUDI V SLOVENIJI
}

\author{
Eva AVGUŠTIN ${ }^{1}$, Maša ZOREC ${ }^{2,3}$
}

Received September 21, 2017; accepted September 28, 2017. Delo je prispelo 21. septembra 2017, sprejeto 28. septembra 2017.

100 let uglednega škotskega inštituta The Rowett Research Institute: vpliv na razvoj mikrobiologije $v$ prehrani domačih živali in ljudi $v$ Sloveniji

Mineva 100 let od nastanka enega od najbolj uglednih raziskovalnih inštitutov na področju prehrane živali in ljudi, škotskega inštituta The Rowett Research Institute (RRI). Poleg izjemnega vpliva na razvoj same znanosti na področju prehrane so bili raziskovalci RRI pomembno vpleteni v razvoj znanosti s področja prehrane, bolj natančno mikrobiologije, povezane s prehrano živali in ljudi, tudi v Sloveniji. Od zgodnjih 1980 let je vrsta slovenskih mikrobiologov gostovala na RRI, tam opravljala raziskave in navezovala stike, od katerih so se nekateri obdržali več kot 40 let. Sodelovanja so bila izjemno plodna, kar se izkazuje skozi skupne znanstvene objave in njihovo odmevnost, izvedbo formalnih in neformalnih raziskovalnih projektov ter sodelovanja pri izvedbi mednarodnih znanstvenih simpozijev. V Sloveniji so raziskovalci, ki so obiskali RRI na osnovi tam pridobljenih znanj izgradili lastne kariere in pomembno sodelovali pri razvoju mikrobiologije doma, med drugim tudi z ustanovitvijo univerzitetnega študija Mikrobiologije, ki bo v kratkem praznoval 25-letnico obstoja, in je po svojih dosežkih $\mathrm{v}$ ponos Biotehniške fakultete in Univerze v Ljubljani.

Ključne besede: raziskovalni inštituti; Rowett Research Institute; Slovenija; mikrobiologija; prehrana živali; prehrana ljudi
100 years of the prestigious Scottish Institute The Rowett Research Institute: the impact on the development of microbiology in nutrition of domestic animals and humans in Slovenia

One century is passing by from the foundation of one of the most respected research institutes in the field of animal and human nutrition, the Scottish Institute The Rowett Research Institute (RRI). In addition to the exceptional influence on the development of the science of nutrition itself, RRI researchers have been significantly involved in the development of science of nutrition and, particularly, of microbiology related to animal and human nutrition in Slovenia. Since the early 1980s, several Slovenian microbiologists have visited RRI, conducted research and developed personal contacts, some retained for more than 40 years. The cooperation was extremely fruitful, which is reflected through joint scientific publications and their visibility, the implementation of formal and informal research projects, and the collaboration in organization of international scientific symposiums. Slovenian researchers, who visited the RRI, built their own careers on the basis of the acquired knowledge and significantly contributed to the development of microbiology in Slovenia. They importantly participated in the establishment of a university study of Microbiology, which will shortly celebrate its 25th anniversary, and is due to its achievements the pride of Biotechnical Faculty and of University of Ljubljana.

Key words: research institutes; The Rowett Research Institute; Slovenia; microbiology; animal nutrition; human nutrition

1 Zoranina ulica 29, SI-1234 Mengeš, Slovenija

2 Univerza v Ljubljani, Biotehniška fakulteta, Oddelek za zootehniko, Domžale, Slovenija

3 Korespondenčni avtor, e-naslov: masa.zorec@bf.uni-lj.si 


\section{UVOD}

Škotski inštitut Rowett Research Institute (RRI) sodi med najbolj ugledne raziskovalne inštitucije na področju prehrane živali in človeka $v$ Evropi in na svetu. $V$ teh letih mineva že 100 let od nastanka te ugledne raziskovalne inštitucije, ki pa je prav v zadnjem obdobju doživela velike organizacijske pretrese. Nekoč samostojni inštitut za prehrano ljudi in živali se je integriral z Univerzo $\mathrm{v}$ Aberdeenu, zapustil zgodovinsko lokacijo in se $\mathrm{v}$ novih prostorih posvetil novim raziskovalnim izzivom, prilagojenim potrebam današnjega časa. Poleg izjemnega pomena za razvoj znanosti na področju prehrane živali in ljudi so imeli raziskovalci RRI izjemen vpliv tudi na razvoj mikrobiologije prebavnega trakta domačih živali in človeka v Sloveniji. Več članov Katedre za mikrobiologijo in mikrobno biotehnologijo Oddelka za zootehniko Biotehniške fakultete se je tam raziskovalno usposabljalo in pridobilo strokovno podlago za uspešno delovanje na raziskovalnem, strokovnem in nenazadnje tudi pedagoškem področju. Mikrobiologija prebavnega trakta je tako pomembno umeščena tudi $\mathrm{v}$ univerzitetne študije Mikrobiologije in Kmetijstva - smer Zootehnika na Biotehniški fakulteti Univerze v Ljubljani (UL), bodisi skozi konkretne predmete, bodisi skozi specifična znanja, vezana na anaerobno mikrobiologijo in interakcije mikroorganizmov z gostiteljem.

\section{ROWETT RESEARCH INSTITUTE: ZGO- DOVINA, UGLED, SEDANJOST}

RRI je nastal leta 1913 na pobudo takratne Univerze $\mathrm{v}$ Aberdeen-u in kmetijskega kolidža (North of Scotland College of Agriculture) zaradi širokega soglasja o nujnosti nastanka raziskovalne ustanove za prehrano živali na Škotskem. Vodenje inštituta so zaupali dr. Johnu Boydu Orru (kasneje Lord Boyd Orr). Orr je sam prispeval $5000 £$ kot prvo donacijo za izgradnjo laboratorijskega poslopja v območju Craibstona, v bližini aberdeenskega primestja Bucksburn. Med prvo svetovno vojno je zaradi Orrove odsotnosti izgradnja inštituta nekoliko zastala, a se je po njegovem povratku leta 1919 nadaljevala. Orr je dosegel, da je vlada Združenega kraljestva sofinancirala izgradnjo raziskovalnega inštituta, ob zagotovilu, da bodo ustanovitelji polovico sredstev zagotovili iz drugih virov. Ta denar je prispeval John Quiller Rowett, premožen vinski trgovec iz Londona. Omogočil je nakup zemljišča in pokritje dela gradbenih stroškov za laboratorijske prostore in poskusne hleve, $\mathrm{z}$ donacijo pa si je zagotovil zavezo, da bo delovanje inštituta $\mathrm{v}$ enaki meri posvečeno raziskavam prehrane živali in ljudi.

$\mathrm{Na}$ isti lokaciji je $\mathrm{z}$ manjšim časovnim zamikom nato zrasla še stavba knjižnice, imenovana Reid Library, za katero je sredstva prispeval Walter A. Reid. Reidova knjižnica je med leti 1923 in 2015 predstavljala najbogatejšo britansko knjižnično zbirko znanstvenega tiska o prehrani. V istem zamahu so zgradili tudi stavbo za potrebe študentov in tujih gostujočih raziskovalcev, The Strathcona House. RRI je uradno odprla leta 1922 žena takratnega kralja Georga V., Marie.

Leta 2008 je RRI prenehal z delovanjem v dotedanji, samostojni obliki in se je pridružil Univerzi v Aberdeenu (UoA), natančneje njenemu Kolidžu za vede o živem in medicini (College of Life Sciences and Medicine) pod imenom Rowett Institute of Nutrition and Health (RINH), začasno pa je še nadaljeval $\mathrm{z}$ delovanjem $\mathrm{v}$ Bucksburnu. V marcu 2016 se je nato RINH preselil v namensko zgrajene prostore na območju univerzitetne medicinske šole UoA v Foresterhillu v Aberdeenu, ki zagotavljajo preko $10000 \mathrm{~m}^{2}$ raziskovalnih površin. Stavbe RRI, vključno z Reidovo knjižnico in Strathcono so porušili, na tem zemljišču pa nameravajo zgraditi novi razstavni in konferenčni center AECC.

$\mathrm{Na}$ RINH so raziskovalne aktivnosti danes organizirane v sklopu štirih najpomembnejših tematik: zdrava prebavila (»gut health«), zdrava presnova (»metabolic health «), debelost in prehranske izbire (»obesity and food choice «) ter življenjske usmeritve in zdravje prebivalstva (»life-course and population health«).

\subsection{DIREKTORJI RRI}

Ugled, prodornost in stabilnost $\mathrm{v}$ delovanju RRI skozi dolga desetletja so nedvomno zasluge izjemnih strokovnjakov, ki so inštitut vodili. Vodstvo inštituta je bilo vedno ponujeno le vrhunskim in izjemno uglednim strokovnjakom iz stroke. Dr. Orr, prvi direktor RRI, je kot zdravnik in prehranski fiziolog pomembno zaznamoval raziskovalno usmeritev RRI, s svojim vplivom na prehransko politiko regije in kasneje celotne države pa je oblikoval tudi socialne in zdravstvene kazalnike nacionalne prehrane. $\mathrm{Z}$ uveljavitvijo obvezne prehrane šoloobveznih otrok je zapustil izjemno dediščino, podobno kot tudi z urejanjem prehranske strategije prebivalstva med drugo svetovno vojno. Njegova enkratna zapuščina $\mathrm{v}$ raziskovalnem delu o vplivu prehrane človeka na njegov socialni položaj in njegovo delo v vlogi prvega direktorja OZN organizacije FAO mu je prinesla leta 1949 Nobelovo nagrado za mir. Bil je član britanske Kraljeve akademije, član številnih akademij v svetu in nosilec številnih častnih doktoratov. Bil je tudi soustanovitelj in prvi predsednik World Academy of Art and Science (WAAS).

Med leti 1945 in 1965 je RRI vodil dr. David Paton Cuthbertson. $\mathrm{Z}$ izrazito usmeritvijo $\mathrm{v}$ raziskave prehrane 
živali je pomembno oblikoval zavedanje pomena avtonomne oskrbe s hrano. Zelo je tudi okrepil infrastrukturo inštituta in razširil raziskovalno sodelovanje doma in $\mathrm{v}$ tujini.

Tretji direktor inštituta je bila dr. Kenneth Lyon Blaxter (1965-1982), ki je kot vrhunski raziskovalec energetskega metabolizma pri prežvekovalcih pustil izjemno sled v uveljavitvi britanske znanosti v svetovnem okolju. Pridobil je plemiški naslov in članstvo v Kraljevi akademiji znanosti. Proti koncu svojega mandata je vse bolj preusmerjal težišče raziskav inštituta $\mathrm{v}$ humano prehrano.

Profesor W. P. T James je vodil inštitut med leti 1982 in 1999 in je tudi sam močno okrepil usmeritev raziskav v humano prehrano s tem, da je ustanovil posebno Enoto humane prehrane. Bil je tudi pobudnik britanske Food Standards Agency.

Trenutno je direktor novega RINH prof. Peter J. Morgan, strokovnjak na področju molekularne endokrinologije, ki je prevzel ustanovo 1999.

\subsection{IZPOSTAVLJENI RAZISKOVALCI RRI}

V stalnem sestavu raziskovalcev je na RRI v vsakem obdobju blestelo nekaj posameznikov s svetovno uveljavljenostjo. Nedvomno je bil eden najbolj uglednih Nobelov nagrajenec Richard Laurence Millington Synge, utemeljitelj porazdelitvene kromatografije.

Raziskovalni projekti so bili na RRI oblikovani $\mathrm{v}$ enotah, ki so smiselno pokrivale fiziološke procese $\mathrm{v}$ prehrani, npr. raziskave o beljakovinah, o maščobah, o ogljikovih hidratih, o mineralih v prehrani. Tudi mikroorganizmi in njihova vloga $\mathrm{v}$ prehrani človeka in živali je imela svoje mesto in RRI je sodil in še vedno sodi med najuglednejše inštitucije $\mathrm{v}$ Evropi in na svetu na tem področju. Skupaj s Francoskim nacionalnim inštitutom za prehrano INRA iz Clermont-Ferranda že vrsto let prireja skupne znanstvene simpozije pod imenom Gut microbiology (https://colloque.inra.fr/inra-rowett-2016/home/ INRA-ROWETT-2016).

Enota pod vodstvom dr. Arpada Pusztaija, ki je raziskovala učinke rastlinskih alkaloidov, zlasti lektinov na živali, si najbrž zasluži posebno omembo. Tudi zaradi odmevne, čeprav sporne afere o vplivu gensko spremenjenih organizmov (GSO), konkretno rastlinske krme, na poskusne miši. Dogodek je v veliki meri soodgovoren za zavračanje prehranske uporabe GSO v svetu, vendar ni bil nikoli dokončno razjasnjen.

Močna enota na RRI pod vodstvom dr. Petra N. Hobsona je pokrivala mikrobiologijo vampa s takrat edinstveno tehniko anaerobne gojitve mikroorganizmov po metodi Američana Roberta E. Hungatea, sicer Hobso- novega dobrega znanca. Ob tem je Hobson v sedemdesetih letih raziskoval tudi biološke procese, ki so spremljali takratne inženirske rešitve obdelave živalskih odpadkov $\mathrm{v}$ anaerobni metanogeni presnovi.

Za slovenske raziskovalce je bila še posebno zanimiva skupina, ki jo je do nedavnega vodil prof. dr. Harry J. Flint. Skupina je še danes aktivna na področju genetike, molekularne biologije in ekologije anaerobnih bakterij iz prebavnega trakta živali in človeka ter interakcij, ki pri tem nastajajo. Število odmevnih znanstvenih objav in posledično ugled te skupine sta izjemna. Prof. Flint je sam in s sodelavci objavil preko 200 znanstvenih člankov, od tega $5 \mathrm{v}$ revijah Nature, ki so bili skupaj citirani več kot 13000-krat.

Prav gotovo moramo omeniti tudi nekatere druge raziskovalce s tega področja, npr. dr. Johna R. Wallacea, ki se je poleg odličnih raziskovalnih dosežkov odlikoval tudi $\mathrm{z}$ izjemnim smislom za sodelovanje $\mathrm{z}$ industrijo. Predvsem je bil aktiven na področju mikrobne razgradnje beljakovin.

Posebno mesto si v tem seznamu zasluži tudi prof. Bob Ørskov. Ta izjemni znanstvenik, po rodu Danec, je s svojim delovanjem na RRI in kasneje tudi drugih inštitutih, predvsem pa s svojim akcijami v tretjem svetu požel svetovno slavo. Kot izjemno ploden znanstvenik, ki je uspel sam in s sodelavci objaviti preko 300 znanstvenih in strokovnih člankov s področja prehrane živali (večino $\mathrm{v}$ času ko je deloval na RRI), je pustil izjemen pečat tudi kot učitelj in pospeševalec razvoja živinoreje v revnih deželah tretjega sveta.

Kot celota so raziskovalci RRI objavili ogromno število znanstvenih del $\mathrm{v}$ najuglednejših mednarodnih revijah (skupaj preko 5000 člankov), med katerimi izstopa vrsta objav v najuglednejših znanstvenih revijah (npr. v zadnjih 45 letih v Nature 9, Science 3 in Lancet 22 objav) in članki $\mathrm{z}$ izjemnim številom citatov (2 članka $\mathrm{z}$ več kot 2000 in 14 člankov $\mathrm{Z}$ več kot 500 citati).

\section{POVEZAVE S SLOVENSKIMI RAZISKO- VALCI: ŠOLANJA, SODELOVANJA, OBJAVE}

Prvi slovenski raziskovalec, ki je obiskal RRI in tam stkal trdne in trajne stike, tako raziskovalne kot osebne, je bil Franc Viktor Nekrep. Že leta 1981 je bil soavtor znanstvenega članka o še danes pomembni tematiki in sicer o vplivu antibiotikov na bakterijske seve iz vampa (Henderson in sod., 1981). Poleg stikov s takrat uveljavljenimi raziskovalci, kot sta bila Colin Henderson in Peter N. Hobson, se je seznanil tudi z mlajšimi vrstniki, ki so v naslednjih letih in desetletjih vodili raziskave na področju anaerobne mikrobiologije in $\mathrm{v}$ svoje laboratorije sprejemali mlajše kolege iz skupine prof. Nekrepa. To 
so bili Colin S. Stewart, Harry J. Flint in John R. Wallace. Cela vrsta asistentov in mladih raziskovalcev, katerih mentor je bil prof. Nekrep, se je koncem 80 . in v 90. letih kalila na RRI in nekateri so tam opravili tudi večino ali vsaj pomemben del svojih doktorskih raziskav (Avguštin, 1992; Gasparič, 1995; Marinšek Logar, 1999; Ramšak, 2000; Čepeljnik, 2005; Vodovnik, 2012). Kasneje so s svojimi škotskimi kolegi plodno sodelovali in doslej skupaj objavili 15 člankov v mednarodnih znanstvenih revijah s faktorjem vpliva (IF) nad 1 (povprečje $>2,5$, mediana $>2,8$, skupno število citatov preko 600), poleg tega pa so predstavili svoje delo še v 16 kongresnih prispevkih $\mathrm{v}$ tujini in 8 prispevkih na kongresih $\mathrm{v}$ domovini.

Raziskovalne tematike, ki so jih slovenski raziskovalci preučevali na RRI, so nato nadaljevali še naprej na Oddelku za zootehniko Biotehniške fakultete. Mnoge od teh tematik so raziskovalno žive še danes. Tako so se ukvarjali s preučevanjem razširjenosti, evolucije in taksonomije po Gramu negativnih bakterij iz rodov Prevotella in Bacteroides (Flint in sod., 1990; Avguštin in sod., 1992, 1994, 1997a; Wood in sod., 1998; Ramšak in sod., 2000) ter tudi z organizacijo genov, odgovornih za sintezo encimov, ki izvajajo razgradnjo rastlinskih polisaharidov pri teh bakterijah (Gasparič in sod., 1995a, 1995b; Miyazaki in sod., 1997; Flint in sod., 2007). Organizacijo encimskih sistemov za razgradnjo strukturnih polisaharidov so preučevali tudi pri po Gramu pozitivnih bakterijah iz vampa prežvekovalcev, in sicer pri bakterijah iz rodov Pseudobuytrivibrio (Čepeljnik in sod., 2006) ter Ruminococcus (Stewart in sod., 1991; Rincon in sod., 2005; 2007; Brulc in sod., 2011; Vodovnik in sod., 2013).

Raziskovalci z Oddelka za zootehniko Biotehniške fakultete so sodelovali pri več raziskovalnih projektih $s$ kolegi z RRI. Posebej bi radi omenili sodelovanje v okviru akcije COST 98, v sklopu katere so sodelovali pri raziskavah o vplivu antinutrientov na prehransko vrednost stročnic. Raziskovalne skupine iz 13 evropskih držav so organizirale izmenjave in sodelovanje strokovnjakov ter pripravljale redna znanstvena srečanja, eno tudi v Sloveniji pod vodstvom prof. dr. F. V. Nekrepa (Gozd Martuljek, 1996). V sklopu tega projekta so organizatorji izdali kar 9 letnikov zbornikov znanstvenih člankov s predstavljenimi predavanji. Skupina prof. Nekrepa je raziskovala predvsem vpliv lektina fitohemaglutinina fižola na bifidobakterije iz prebavil laboratorijskih podgan (Avguštin in sod. 1996, 1999; Avguštin, 2000; Fanedl in sod., 1999, 2000, Ramšak in Avguštin, 2000).

Vsekakor moramo omeniti tudi raziskovalca s Kmetijskega inštituta Slovenije, dr. Jožeta Verbiča, ki sicer ni mikrobiolog, je pa v času svojih delovnih obiskov na RRI pri znamenitem profesorju Bobu Ørskovu delal na tematikah, ki so se mikrobiologije vsaj dotikale. Tako je s sodelavci opisal vpliv dodajanja infuzije mikrobnih nukleinskih kislin na izločanje purinskih derivatov pri prežvekovalcih (Verbič in sod., 1990) in vpliv načina skladiščenja krme na razgradljivost beljakovin in sintezo mikrobnih beljakovin v vampu (Verbič in sod., 1999). Oba prispevka sta doživela precejšnjo pozornost v znanstvenem svetu, predvsem prvi, ki je bil doslej citiran že več kot 200-krat.

\section{POVEZAVE Z DRUGIMI RAZISKOVALCI, KI SO NASTALE NA ROWETTU}

Znanje, ki so ga slovenski mikrobiologi pridobili na RRI, in znanstvene objave, ki so jih objavili v sodelovanju s kolegi z RRI, niso edina pozitivna posledica povezav z aberdeenskim inštitutom. Poleg škotskih kolegov so Slovenci tam spoznali še celo vrsto znanstvenikov, ki so na RRI gostovali. Med temi je na prvem mestu potrebno omeniti dr. Jana Kopečny-a s Češke akademije znanosti (CAS). Dr. Kopečny je navezal tesne stike z več slovenskimi raziskovalci, ki so prerasli $\mathrm{v}$ dolgoletno in izjemno plodno sodelovanje. Poleg strokovnih obiskov in izmenjav ter skupnih znanstvenih objav se to morda najbolje kaže skozi sodelovanje pri organizaciji serije kongresov pod kratico ISAM (International Symposium on Anaerobic Microbiology). Simpozij se je v dokaj skromni obliki začel kot neformalno srečanje slovenskih in čeških znanstvenikov leta 1998 v Sloveniji in je do danes doživel že 9. uradno ponovitev v skupni organizaciji kolegov iz CAS, Slovaške akademije znanosti in Univerze v Innsbrucku. Simpozijev se je doslej udeležilo preko 500 znanstvenikov iz več kot 20 držav, izbor znanstvenih prispevkov pa je bil objavljen v revijah Folia Microbiologica in Anaerobe. Zadnji, 10. simpozij, je letos potekal na Češkem (http://www.10-isam.cz/).

\section{ZAKLJUČEK}

Ob častitljivi 100. obletnici delovanja škotskega inštituta Rowett Research Institute v Aberdeenu lahko ugotovimo, da je delo in odprtost ter pripravljenost za sodelovanje raziskovalcev RRI imelo velik vpliv tudi na razvoj mikrobiologije v Sloveniji. Znanstveniki z RRI so omogočili slovenskim mikrobiologom dostop do najmodernejših metodologij in pomembnih novih znanj iz sveta anaerobne mikrobiologije, kar jim je ob vzpostavitvi ustrezne raziskovalne infrastrukture omogočilo hitrejši razvoj doma. Slovenski mikrobiologi z Oddelka za zootehniko Biotehniške fakultete so nato pomembno sodelovali pri izgradnji novega univerzitetnega študija Mikrobiologije na Biotehniški fakulteti Univerze v Ljubljani 
(glej Raspor in sod., 2013) in skrbijo za nadaljnji razvoj anaerobne mikrobiologije še danes.

\section{ZAHVALA}

Avtorici se zahvaljujeta vsem, ki so prispevali pomembne informacije za pripravo članka, predvsem zaslužnemu profesorju dr. Francu V. Nekrepu, za vso nesebično pomoč in čas, ki so nama ga namenili.

\section{$7 \quad$ VIRI}

Avguštin, G. (1992). Analiza vloge bakterije Prevotella (Bacteroides) ruminicola $v$ vampnem ekosistemu $z$ molekularnimi genetskimi metodami (doktorska disertacija). Univerza $\mathrm{v}$ Ljubljani, Biotehniška fakulteta, Ljubljana.

Avguštin, G. (2000). Effects of antinutrients on the gut microflora. V A. Krogdahl, S. Mathiesen, I. A. Pryme (ur.), Effects of antinutrients on the nutritional value of legume diets (pp. 85-90). Luxembourg: Office for Official Publications of the European Communities.

Avguštin, G., Fanedl, L., Nekrep, F. V. (1996). Bifidobacteria from PHA stressed gut. V S. Bardocz, F. V. Nekrep, A. Pusztai (ur.). Effects of antinutrients on the nutritional value of legume diets. Vol. 3, Impact of food antinutrients on the microbial ecology of the gut (pp. 21-28). Luxembourg: Office for Official Publications of the European Communities.

Avguštin, G., Fanedl, L., Nekrep, F. V. (1999). The in vitro effects of PHA on growth of bifidobacteria from rat gut. V E. Carnovale (ur.), Effects of antinutrients on the nutritional value of legume diets (pp. 105-110). Luxembourg: Office for Official Publications of the European Communities.

Avguštin, G., Flint, H. J., Whitehead, T. R. (1992). Distribution of xylanase genes and enzymes among strains of Prevotella (Bacteroides) ruminicola from the rumen. FEMS Microbiology Letters, 99, 137-144. https://doi.org/10.1111/j.1574-6968.1992.tb05556.x

Avguštin, G., Wallace, J. R., Flint, H. J. (1997). Phenotypic diversity among ruminal isolates of Prevotella ruminicola: proposal of Prevotella brevis sp. nov., Prevotella bryantii sp. nov., and Prevotella albensis sp. nov. and redefiniton of Prevotella ruminicola. International Journal of Systematic Bacteriology, 47(2): 284-288. https://doi.org/10.1099/0020771347-2-284

Avguštin, G., Wright, F., Flint, H.J. (1994). Genetic diversity and phylogenetic relationships among strains of Prevotella (Bacteroides) ruminicola from the rumen. International Journal of Systematic Bacteriology, 44(2), 246-255. https://doi.org/10.1099/00207713-44-2-246

Brulc, J. M., Yeoman, C. J., Wilson, M. K., Berg Miller, M. E., Jeraldo, P., Jindou, S. ... White, B. A. (2011). Cellulosomics, a gene-centric approach to investigating the intraspecific diversity and adaptation of Ruminococcus flavefaciens within the rumen. PloS one, 6(10), 1-10, e25329.

https://doi.org/10.1371/journal.pone.0025329
Čepeljnik, T. (2005). Multiple ksilanaze vampne bakterije Pseudobutyrivibrio xylanivorans $M z 5 T$ in možnosti njene probiotske uporabe (doktorska disertacija). Univerza v Ljubljani, Biotehniška fakulteta, Ljubljana.

Čepeljnik, T., Rincón, M. T., Flint, H. J., Marinšek-Logar, R. (2006). XYN11A, a multidomain multicatalytic enzyme from Pseudobutyrivibrio xylanivorans Mz5T. Folia Microbiologica, 51(4), 263-267. https://doi.org/10.1007/ BF02931809

Fanedl, L., Tepšič, K., Nekrep, F. V., Avguštin, G. (1999). Lectins-microorganism interactions: in situ monitoring of bacterial populations in the gut. V S. Bardocz, G. Hajos, A. Pusztai (ur.), Effects of antinutrients on the nutritional value of legume diets. Vol. 6 (pp. 166-169). Luxembourg: Office for Official Publications of the European Communities.

Fanedl, L., Nekrep, F. V., Avguštin, G. (2000). Detection of bacterial populations inhabiting the gut of kidney bean fed rats with specific PCR reactions. V Ĩ. Krogdahl, S.D. Mathiesen, I.F. Pryme (ur.), Effects of antinutrients on the nutritional value of legume diets (pp. 81-84). Luxembourg: Office for Official Publications of the European Communities.

Flint, H. J., Macpherson, C. A., Avguštin, G., Stewart, C. S. (1990). Use of a cellulase-encoding gene probe to reveal restriction fragment lenth polymorphisms among ruminal strains of Bacteroides succinogenes. Current Microbiology, 20(1), 63-67. https://doi.org/10.1007/BF02094027

Flint, H. J., Whitehead, T. R., Martin, J. C., Gasparič, A. (2007). Interrupted catalytic domain structures in xylanases from two distantly related strains of Prevotella ruminicola. Biochimica et Biophysica Acta, Protein Structure and Molecular Enzymology, 1337(2), 161-165. https://doi.org/10.1016/ S0167-4838(96)00213-0

Gasparič, A. (1995). Kloniranje in opis nekaterih genov ksilanolitičnega kompleksa bakterije Prevotella rumini-

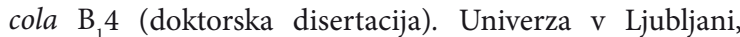
Biotehniška fakulteta, Domžale.

Gasparič, A., Marinšek-Logar, R., Martin, J., Wallace, J. R., Nekrep, F. V., Flint, H. J. (1995a). Isolation of genes encoding beta-D-xylanase, beta-D-xylosidase and alfa-Larabinofuranosidase activities from the rumen bacterium Prevotella ruminicola $\mathrm{B}_{1} 4$. FEMS Microbiology Letters, 125, 135-142.

Gasparič, A., Martin, J., Daniel, A. S., Flint, H. J. (1995b). A xylan hydrolase gene cluster in Prevotella ruminicola $\mathrm{B}_{1} 4$ : sequence relationships, synergistic interactions, and oxygen sensitivity of a novel enzyme with exoxylanase and beta-(1,4)-xylosidase activity. Applied And Environmental Microbiology, 61(8), 2958-2964.

Henderson, C., Stewart, C. S., Nekrep, F. V. (1981). The effect of monesin on pure and mixed cultures of rumen bacteria. Journal of Applied Bacteriology, 51, 159-169. https://doi.org/10.1111/j.1365-2672.1981.tb00920.x

Marinšek-Logar, R. (1999). Opis ksilanolitičnega encimskega sistema vampne bakterije Prevotella bryantii $B_{1} 4$ (doktorska disertacija). Univerza v Ljubljani, Biotehniška fakulteta, Domžale.

Miyazaki, K., Martin, J. C., Marinšek-Logar, R., Flint, H. J. (1997). Degradation and utilization of xylans by the rumen anaerobe Prevotella bryantii (formerly P. ruminicola subsp. 
brevis) B 4. Anaerobe, 3, 373-381. https://doi.org/10.1006/ anae.1997.0125

Ramšak, A. (2000). Z analizo $16 S$ rRNA ugotovljena raznolikost bakterijske populacije v vzorcu iz vampa goveda (doktorska disertacija). Univerza v Ljubljani, Biotehniška fakulteta, Domžale.

Ramšak, A., Avguštin, G. (2000). RFLP analysis and phylogenetic diversity of rumen bacteria. V Ã. Krogdahl, S. D. Mathiesen, I. F. Pryme (ur.), Effects of antinutrients on the nutritional value of legume diets (pp. 91-95). Luxembourg: Office for Official Publications of the European Communities.

Ramšak, A., Peterka, M., Tajima, K., Martin, J. C., Wood, J., Johnston, M. E. A., ... Avguštin, G. (2000). Unravelling the genetic diversity of ruminal bacteria belonging to the CFB phylum. FEMS Microbiology, Ecology, 33, 69-79. https://doi.org/10.1111/j.1574-6941.2000.tb00728.x

Raspor, P. (glavni ur.), Avguštin, G. (ur.), Mandić-Mulec, I. (ur.), Marinšek-Logar, R. (ur.), Petrovec, M. (ur.), Sepčić, K. (ur.), Stopar, D. (ur.), Stres, B. (ur.), Zalar, P. (ur.), ŽgurBertok, D. (ur.). (2013). Mikrobiologija za znanje in napredek : 20 let univerzitetnega študija mikrobiologije. Ljubljana: Biotehniška fakulteta, Oddelek za živilstvo, Katedra za biotehnologijo, mikrobiologijo in varnost živil.

Rincon, M. T., Čepeljnik, T., Martin, J. C., Barak, Y., Lamed, R., Bayer, E. A., Flint, H. J. (2007). A novel cell surface-anchored cellulose-binding protein encoded by the sca gene cluster of Ruminococcus flavefaciens. Journal of Bacteriology, 189(13): 4774-4783. https://doi.org/10.1128/JB.00143-07

Rincon, M. T., Čepeljnik, T., Martin, J. C., Lamed, R., Barak, Y., Bayer, E. A., Flint, H. J. (2005). Unconventional mode of attachment of the Ruminococcus flavefaciens cellulosome to the cell surface. Journal of Bacteriology, 87(22), 7569-7578. https://doi.org/10.1128/JB.187.22.7569-7578.2005

Stewart, C. S., Flint, H. J., Nekrep, F. V. (1991). Degradation of plant cell wall polymers by the anaerobic rumen bacterium Ruminococcus flavefaciens. V G. C. Galletti (ur.), Production and utilization of lignocelulosics : plant refinery and breeding, analysis, feeding to herbivores, and economic aspects (pp. 387-399). London; New York: Elsevier.

Verbič, J., Chen, X. B., Macleod, N. A., Ørskov, E. R. Excretion of purine derivates by ruminants : effect of microbial nucleic acid infusion on purine derivate excretion by steers. The Journal of Agricultural Science, 114(3), 243-248. https://doi.org/10.1079/BJN19900098

Verbič, J., Ørskov, E. R., Žgajnar, J., Chen, X. B., Žnidaršič Pongrac, V. (1999). The effect of method of forage preservation on the protein degradability and microbial protein synthesis in the rumen. Animal Feed Science and Technology, 82(3/4), 195-212. https://doi.org/10.1016/S0377-8401(99)00102-9

Vodovnik, M. (2012). Celulolitični sistem sevov 007C in 007S bakterije Ruminococcus flavefaciens (doktorska disertacija). Univerza v Ljubljani, Biotehniška fakulteta, Ljubljana.

Vodovnik, M., Duncan, S. H., Reid, M. D., Cantlay, L., Turner K., Parkhill, J., ... Flint, H. J. (2013). Expression of cellulosome components and type IV pili within the extracellular proteome of Ruminococcus flavefaciens 007. PloS one, 8(6), 1-11, e-65333. https://doi.org/10.1371/journal. pone.0065333

Wood, J., Scott, K. P., Avguštin, G., Newbold, C. J., Flint, H. J. (1998). Estimation of the relative abundance of different Bacteroides and Prevotella ribotypes in gut samples by restriction enzyme profiling of PCR-amplified $16 \mathrm{~S}$ rRNA gene sequences. Applied And Environmental Microbiology, 64(10), 3683-3689. 